\title{
PRODUCTIVITY OF YOUNG RABBITS AT DIFFERENT SOURCES OF CUPRUM IN THE MIXED FODDER
}

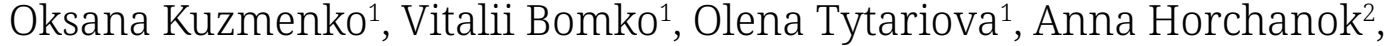

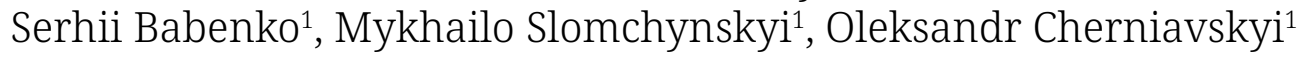 \\ ${ }^{1}$ Department of Technology of Feed, Feed Additives and Feeding of Animals, Faculty of Biotechnological, Bila \\ Tserkva National Agrarian University, 8/1, Soborna pl., Bila Tserkva, Kyiv region, Ukraine \\ ${ }^{2}$ Department of Water and Aquaculture Bioresourses, Faculty of Biotechnological, Dnipro State Agrarian and \\ Economic University, Serhii Yefremov street, 25, Dnipro, Ukraine
}

Link to this article: https://doi.org/10.11118/actaun.2021.017

Received: 18. 12. 2020, Accepted: 24. 2. 2021

To cite this article: KUZMENKO OKSANA, BOMKO VITALII, TYTARIOVA OLENA, HORCHANOK ANNA, BABENKO SERHII, SLOMCHYNSKYI MYKHAILO, CHERNIAVSKYI OLEKSANDR. 2021. Productivity of Young Rabbits at Different Sources of Cuprum in the Mixed Fodder. Acta Universitatis Agriculturae et Silviculturae Mendelianae Brunensis, 69(2): 203-209.

\begin{abstract}
The impact of different levels and sources of coppermixedligand on productivity and its metabolism in young rabbits of California breed in combination with sulfates was investigated in experiment. For rabbits of the $1^{\text {st }}$ control group $7.81 \mathrm{~g} / \mathrm{t}$ of copper sulfate was injected into the mixed fodder, of the $2^{\text {nd }}$ experimental group $-7.81 \mathrm{~g} / \mathrm{t}$ of coppermixedligand, of the $3^{\text {rd }}, 4^{\text {th }}$ and $5^{\text {th }}$ experimental groups, respectively, g/t: 5.86; 3.91 and 1.95. As a result, the rabbits of the $1^{\text {st }}$ control group and the $2^{\text {nd }}$ experimental group deficit of copper was eliminated by $100 \%$ to the existing norm, and the rabbits of the $3^{\text {rd }}, 4^{\text {th }}$ and $5^{\text {th }}$ experimental groups - by 75,50 and $25 \%$.

Studies have shown that during the main period of the experiment, the increase in live weight in all experimental groups exceeded the indicator of the control group. In particular, in rabbits of the $2^{\text {nd }}$ experimental group this exceeding was $9.0 \%(p<0.05), 3^{\text {rd }}-13.2 \%(p<0.05), 4^{\text {th }}-14.0 \%(p<0.001)$ and $5^{\text {th }}$ - by $4.9 \%$. Among all the experimental groups, the best indicators of nutrient digestibility of feed were the rabbits of the $4^{\text {th }}$ experimental group, which in the composition of the mixed fodder fed coppermixedligand, which covered a deficiency of this element by 50\% in metal chelate from the amount of Copper of the $2^{\text {nd }}$ experimental group. Compared to control group the digestibility rate of organic feed matter in these animals increased by 3.7\%. This increase was due to an increase in the digestibility of crude protein - by $4.5 \%$, crude fat -0.5 , crude fiber -4.6 and nitrogen-free extractives $-3.7 \%$. According to the results of the experiment, the rabbits of the experimental group 4 ate $5.0 \%$ less feed than the counterparts of the $1^{\text {st }}$ control group, and the feed costs were $3.9 \%$ lower. The use of the organic form of copper in the form of mixed-ligand complex in mixfeed for rabbits of breeding on meat in the amount of $3.91 \mathrm{~g} / \mathrm{t}$ or $50 \%$ of metalchelate promoted an increase in the growth of animals, nutrient digestibility of feed and reduced feed conversion.
\end{abstract}

Keywords: young rabbits, trace elements, copper sulfate, coppermixedligand, productivity, digestibility

\section{INTRODUCTION}

As biological characteristics of rabbits include intensive breeding and high maturity of young animals, these animals place high demands on feeding, which should be complete. Complete feeding of rabbits in most farms in Ukraine is provided with complete mixed fodder (Darmohray et al., 2015). 
In order to live a rabbit requires proteins, fats, carbohydrates, vitamins, macro- and trace elements and even aromatic substances (Johnson-Delaney, 2006; Mateos et al., 2020). The lack of any element of nutrition in the body adversely affects its growth and development. It is necessary that the nutrient supply to the body should be combined with the digestion and be within the physiological norm (Maertens et al., 2006; Predieri et al., 2005).

The trace elements are known to belong to a group of biologically active substances that affect the growth, productivity and reproduction of animals. The trace elements cannot be replaced by other substances, and their deficiency must be eliminated at the expense of basic feeds and various additives (Beshkenadze et al., 2016). In addition, the traditional sources of trace elements in the mixedfodder for rabbits are mineral salts in the form of sulfate and chloride compounds and their bioavailability is $12-35 \%$. The content of sulfates and chlorides leads to environmental pollution by heavy metals, and the crystallized water contained in the premix sulfate molecules destroys vitamins and other biologically active substances (Cobanova et al., 2018; Tchounwou et al., 2012).

Today, detailed feeding standards for rabbits include the introduction of such trace elements as Ferrum, Copper, Zinc and Manganese into the diet. The daily requirement for young rabbits should be: Ferrum - 32-55 mg, Zinc - 10-14 mg, Copper2-2.3 mg and Manganese - 6-8 mg (Mateos et al., 2020). However, detailed standards of European standards provide for a $20-50 \%$ higher level of trace elements in the diets of rabbits, especially of organic origin.

Previous studies on the bioavailability of chelates have shown that at the use of feed additives with trace elements of organic origin, the degree of absorption of trace elements increases (Paik, 2001; Zhu et al., 2019). Representatives of such feed additives are mixed ligand complexes of trace elements (chelates).

Thus, the study of the action of coppermixedligand in the mixed fodder for young rabbits grown for meat, determining the optimal amount of this supplement is important scientifically and practically.

\section{MATERIALS AND METHODS}

To evaluate the productive effect of mixed-ligand complex of Copper and to establish the optimal feeding dose, a scientific and economic experiment was conducted in the conditions of the Bila Tserkva National Agrarian University (Ukraine) vivarium.

The scheme of scientific economic experiment is presented in the Tab. I.

To conduct scientific and economic experiment 50 heads of rabbits of the Californian breed aged 45 days were selected. 5 groups were formed by the method of groups (analog pairs), each of which consisted of 3 females and 7 males. Animals were housed in mesh cages that were housed in a singletier type. The rabbits had access to water and feed daily.

For experimental animals feeding a complete mixed fodder was used, balanced according to the detailed feeding standards of young rabbits according to their age (45-60, 61-90, 91-120 days). The difference in feeding in the experimental period was that within 15 days the control group was fed a premix of the preparatory period, which contained sulfates of Ferrum, Zinc, Manganese and Copper, and the rabbits of the experimental groups - instead of Copper sulphate were fed coppermixedligand. In terms of the pure element, the experimental rabbits of the $2^{\text {nd }}$ experimental group received the same amount of pure Copper as the rabbits of the $1^{\text {st }}$ control group, and in the $3^{\text {rd }} 4^{\text {th }}$ and $5^{\text {th }}$ experimental groups of rabbits, the coppermixedligand covered the deficiency of this

I: The scheme of conducting the scientific economic experiment

\begin{tabular}{|c|c|c|c|}
\hline \multirow[b]{2}{*}{ Group } & \multirow{2}{*}{$\begin{array}{l}\text { The number } \\
\text { of heads } \\
\text { in the group }\end{array}$} & \multicolumn{2}{|r|}{ Period of the experiment } \\
\hline & & $\begin{array}{l}\text { Comparative } \\
\text { (15 days) }\end{array}$ & Main (75 days) \\
\hline 1 control & 10 & $\mathrm{CF}^{*}$ & $\begin{array}{l}\text { Complete mixed fodder with sulfates: Ferum } 179.2 \mathrm{~g} / \mathrm{t} \text {, Zinc } 44.1 \mathrm{~g} / \mathrm{t} \text {, } \\
\text { Copper } 5.4 \mathrm{~g} / \mathrm{t} \text { and Manganese } 8.4 \mathrm{~g} / \mathrm{t}(100 \% \text { of the need provided to } \\
\text { sulfates) }\end{array}$ \\
\hline 2 experimental & 10 & $\mathrm{CF}$ & $\begin{array}{l}\text { CF with sulfates and chelate of Copper } 7.81 \mathrm{~g} / \mathrm{t} \text { (100\% of the need } \\
\text { of copper provided to coppermixedligand) }\end{array}$ \\
\hline 3 experimental & 10 & $\mathrm{CF}$ & $\begin{array}{l}\text { CF with sulfates and chelate of Copper } 5.86 \mathrm{~g} / \mathrm{t} \text { ( } 75 \% \text { of the need of copper } \\
\text { provided to coppermixedligand) }\end{array}$ \\
\hline 4 experimental & 10 & $\mathrm{CF}$ & $\begin{array}{l}\text { CF with sulfates and chelate of Copper } 3.91 \mathrm{~g} / \mathrm{t} \text { (50\% of the need of copper } \\
\text { provided to coppermixedligand) }\end{array}$ \\
\hline 5 experimental & 10 & $\mathrm{CF}$ & $\begin{array}{l}\text { CF with sulfates and chelate of Copper } 1.95 \mathrm{~g} / \mathrm{t} \text { ( } 25 \% \text { of the need of copper } \\
\text { provided to coppermixedligand) }\end{array}$ \\
\hline
\end{tabular}

Note: ${ }^{*} \mathrm{CF}$ - complete mixed fodder 


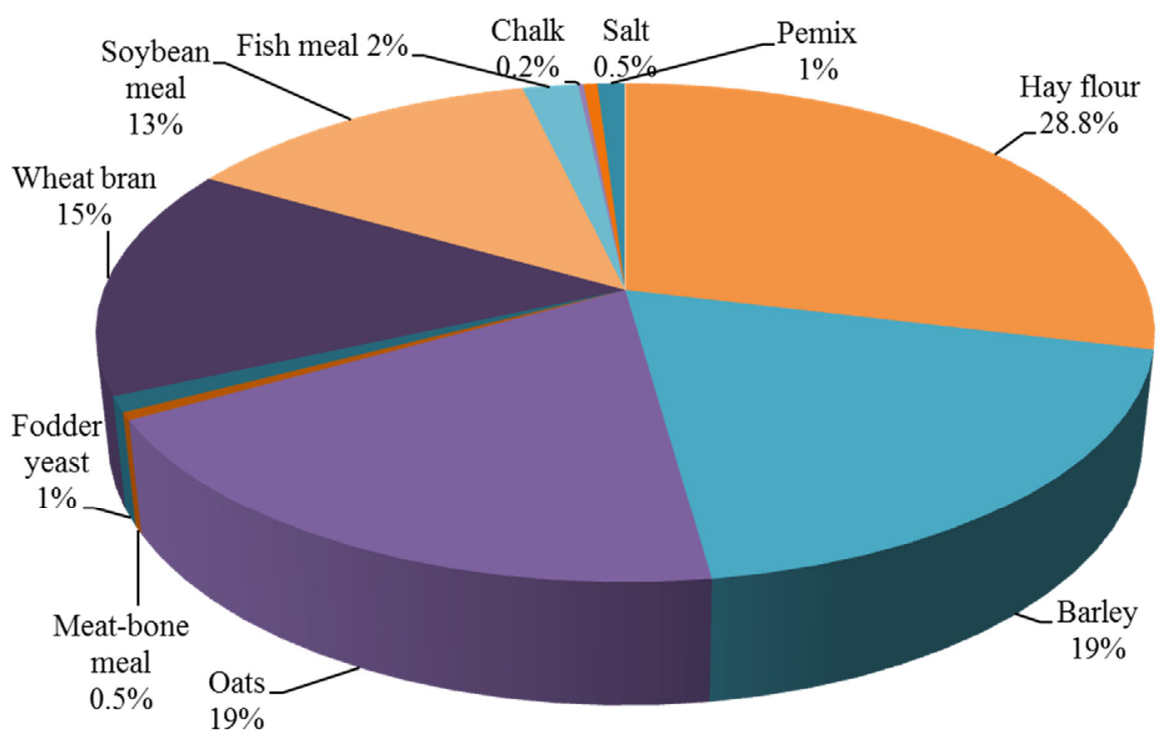

1: The composition of mixed fodder rabbits

element at 75, 50 and 25\% by metal chelate from the amount of Copper of the $2^{\text {nd }}$ experimental group, which was $7.81 \mathrm{~g} / \mathrm{t}$ for the $2^{\text {nd }}$ experimental group, $5.86 \mathrm{~g} / \mathrm{t}$ for the $3^{\text {rd }}$ experimental group, for the $4^{\text {th }}$ experimental group $3.91 \mathrm{~g} / \mathrm{t}$ and the $5^{\text {th }}$ experimental group $-1.95 \mathrm{~g} / \mathrm{t}$ of mixed fodder.

The composition of mixed fodder is shown in Fig. 1. The premix composition was designed to fully meet the animal's need for biologically active substances. Rabbits from 45- to 120-days-old were fed a mixed fodder which consisted of the following components: grain - 84.3\%; meal - 13\%; mineral supplements and vitamin preparations - $2.7 \%$. Compound feeds fully provided the need for rabbits for nutrients.

The content of nutrients and biologically active substances in $1 \mathrm{~kg}$ of mixed fodder for young rabbits of experimental groups grown for meat was the same and met the guidelines for nutrition normalization of young rabbits approved by the VIII International Rabbit Husbandry Congress (Maertes et al., 2002).

In the experiment, we studied the live weight of rabbits, kept records of the safety and mass of the consumed mixed fodder. Absolute, average daily and relative gains in live weight and feed costs per $1 \mathrm{~kg}$ of weight gain were also calculated.

At the age of 90 days a physiological experiment to study the digestibility of nutrients was conducted. For this purpose, from each group on the principle of analogues 3 heads ( 2 males and 1 female) were selected. Rabbits were housed individually in specially equipped cages for nutrient digestion experiments. During the preparatory period of three days, rabbits were accustomed to changing conditions of confinement. During the accounting period of six days, the amount of mixed fodder and excreted feces and urine was calculated daily for each animal. Feces were harvested once a day
- in the evening, urine - twice - in the morning and in the evening. After weighing the feces, a 10\% hydrochloric acid solution was preserved at a rate of $1.5 \mathrm{ml}$ per $100 \mathrm{~g}$ of feces. Samples of missed fodder were sealed in plastic bags. Prior to the zootechnical analysis, feces and urine samples were stored in a refrigerated chamber in a tightly closed container. Traditional methods of zootechnical analysis were used for research. The amount of digestible nutrients of the feed (protein, fat, fiber, nitrogen free extractives substances) was determined by the difference between the nutrient content of the feed consumed and the allocated feces.

\section{RESULTS}

The main indicator by which the performance of rabbits can be evaluated is the dynamics of live weight and the nutrient digestibility of feed. Along with this, an indicator such as feed costs is equally important. These indicators give a more complete assessment of the feasibility of using Copper sulphate and coppermixedligand in the mixed fodder for rabbits grown for meat.

Feeding of young rabbits of experimental groups mixed fodder with coppermixedligand affected their growth (Tab. II).

The results of weighing rabbits at the age of 60 days give grounds to claim that the animals selected for the experiment were as similar in performance as possible. Control weighing of rabbits at the age of 90 days showed that different sources of Copper did not have the same result on productivity of young rabbits.

After 30 days from the beginning of the consumption of mixed fodder with different contents of coppermixedligand, animals of all experimental groups dominated analogues of the control group in live weight. The largest intergroup difference was 
II: Dynamics of live weight of experimental rabbits, $g$

\begin{tabular}{|c|c|c|c|c|c|}
\hline \multirow{3}{*}{ Indicator } & \multicolumn{5}{|c|}{ Group } \\
\hline & \multirow{2}{*}{$\begin{array}{c}\text { Control } \\
1\end{array}$} & \multicolumn{4}{|c|}{ Experimental } \\
\hline & & 2 & 3 & 4 & 5 \\
\hline \multicolumn{6}{|c|}{ Live weight at the age: } \\
\hline 60 days & $1110.9 \pm 15.32$ & $1105.5 \pm 19.34$ & $1104.3 \pm 16.45$ & $1106.2 \pm 15.73$ & $1109.0 \pm 14.37$ \\
\hline 90 days & $2131.5 \pm 32.56$ & $2261.7 \pm 34.24^{*}$ & $2245.2 \pm 22.57^{*}$ & $2276.6 \pm 31.74^{*}$ & $2208.3 \pm 28.62$ \\
\hline 120 days & $3005.8 \pm 48.33$ & $3170.9 \pm 46.27$ & $3250.1 \pm 54.39 *$ & $3267.1 \pm 37.44^{* *}$ & $3096.4 \pm 39.18$ \\
\hline \multicolumn{6}{|c|}{ Average daily weight gain during the period: } \\
\hline 61-120 days & $31.6 \pm 0.76$ & $34.4 \pm 0.84^{*}$ & $35.8 \pm 0.92^{* *}$ & $36.0 \pm 0.88^{* * *}$ & $33.1 \pm 0.67$ \\
\hline
\end{tabular}

Note: ${ }^{*} p<0.05 ;{ }^{* *} p<0.01 ;{ }^{* *} p<0.001$ in compare with control group

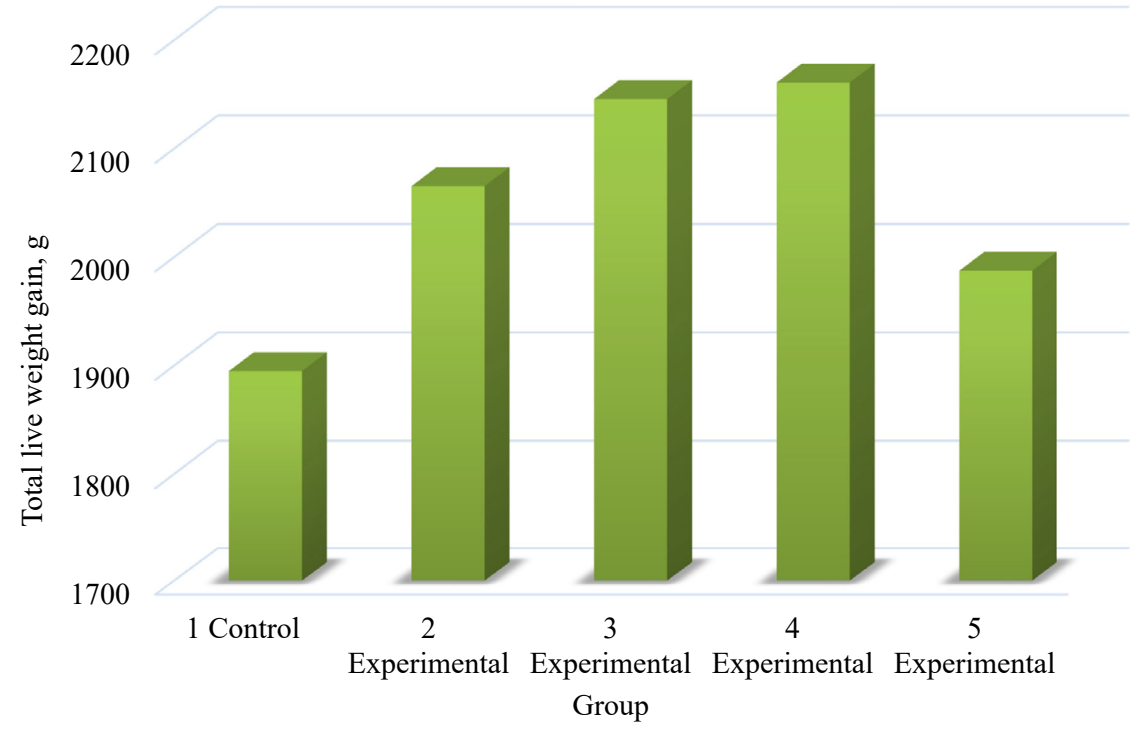

2: Total live weight gain of rabbits, $g$

observed in animals of the $4^{\text {th }}$ experimental group $-6.8 \%$ ( $p<0.05$ ). The live weight of rabbits of the $2^{\text {nd }}$ and $3^{\text {rd }}$ experimental groups was higher than the control by 6.1\% ( $<<0.05)$ and 5.3\% ( $<0.05)$, respectively. The lowest indicator in this group was in the group 5 - only $3.6 \%$ compared to controls.

At the age of 120 days, the weight gain of rabbits of the $2^{\text {nd }}$ experimental group over the rabbits of the control group by live weight decreased slightly and was 5.5\%, the difference was not reliable. Indicators of the $3^{\text {rd }}$ experimental group were significantly improved, the live weight of rabbits exceeded the weight of the animals of the control by $8.1 \%(p<0.05)$. The rabbits of the $4^{\text {th }}$ experimental group maintained the leadership, and their live weight exceeded the control by $8.7 \%$ ( $p<0.01)$. Prolonged feeding of coppermixedligand to rabbits of the $5^{\text {th }}$ experimental group had less significant effect on the live weight. Their live weight exceeded control by only 3.0\%. Obviously, the dose of the coppermixedligand was somewhat low, which impeded the growth of animals of the $5^{\text {th }}$ experimental group compared with the rabbits of the $3^{\text {rd }}$ and $4^{\text {th }}$ experimental groups.

For the entire main period of the experiment, which coincides with the 61-120-days age of the experimental rabbits (Fig. 2), the total increase in their live weight in all experimental groups exceeded this indicator compared to the control. In particular, in rabbits of the $2^{\text {nd }}$ experimental group this excess was 9.0\% ( $p<0.05), 3^{\text {rd }}-13.2 \%(p<0.05)$, $4^{\text {th }}-14.0 \%(\mathrm{p}<0.01)$ and $5^{\text {th }}-$ by $4.9 \%$.

Addition of coppermixedligand the mixed fodder for young rabbits in the amount of 100\%, 75, 50 and $25 \%$ at metal chelate contributed to the increase and their daily average gains. In particular, during the main experimental period (61-120 days), advantage of the animals from the 2, 3, 4 and 5 experimental groups in compare with the control group animals were 8.8\% ( $p<0.05)$; 13.3\% ( $<<0.01) ; 13.9 \%$ $(p<0.001)$ and $4.7 \%$.

Data about the influence of organic form of Copper in the form of a mixed ligand complex for the digestibility of nutrients of feed in the rabbits of the experimental groups are shown in Tab. III. 
III: Digestive nutrient coefficients of feed ( $n=3, M \pm m), \%$

\begin{tabular}{lccccc}
\hline \multirow{2}{*}{\multicolumn{1}{c}{ Indicator }} & \multicolumn{5}{c}{ Group } \\
\cline { 2 - 6 } & \multicolumn{2}{c}{ Control } & \multicolumn{4}{c}{ Experimental } \\
\cline { 2 - 6 } & 1 & 2 & 3 & 4 & 5 \\
\hline Organic substance & $69.5 \pm 0.46$ & $70.7 \pm 0.52$ & $71.4 \pm 0.77$ & $72.1 \pm 0.82$ & $70.1 \pm 0.69$ \\
Crude protein & $70.7 \pm 0.63$ & $72.8 \pm 0.44$ & $73.4 \pm 1.12$ & $73.9 \pm 0.64^{*}$ & $72.1 \pm 1.21$ \\
Crude fat & $80.5 \pm 1.02$ & $80.6 \pm 0.68$ & $80.7 \pm 1.03$ & $80.9 \pm 1.24$ & $79.5 \pm 0.82$ \\
Crude cellulose & $30.1 \pm 0.75$ & $30.5 \pm 1.08$ & $31.4 \pm 1.17$ & $31.5 \pm 1.05$ & $30.5 \pm 0.76$ \\
Nitrogen free extractives substances & $78.8 \pm 0.86$ & $79.9 \pm 1.20$ & $80.8 \pm 0.88$ & $81.7 \pm 1.07$ & $79.3 \pm 0.93$ \\
\hline
\end{tabular}

Note: ${ }^{*} p<0.05$ in compare with the control group

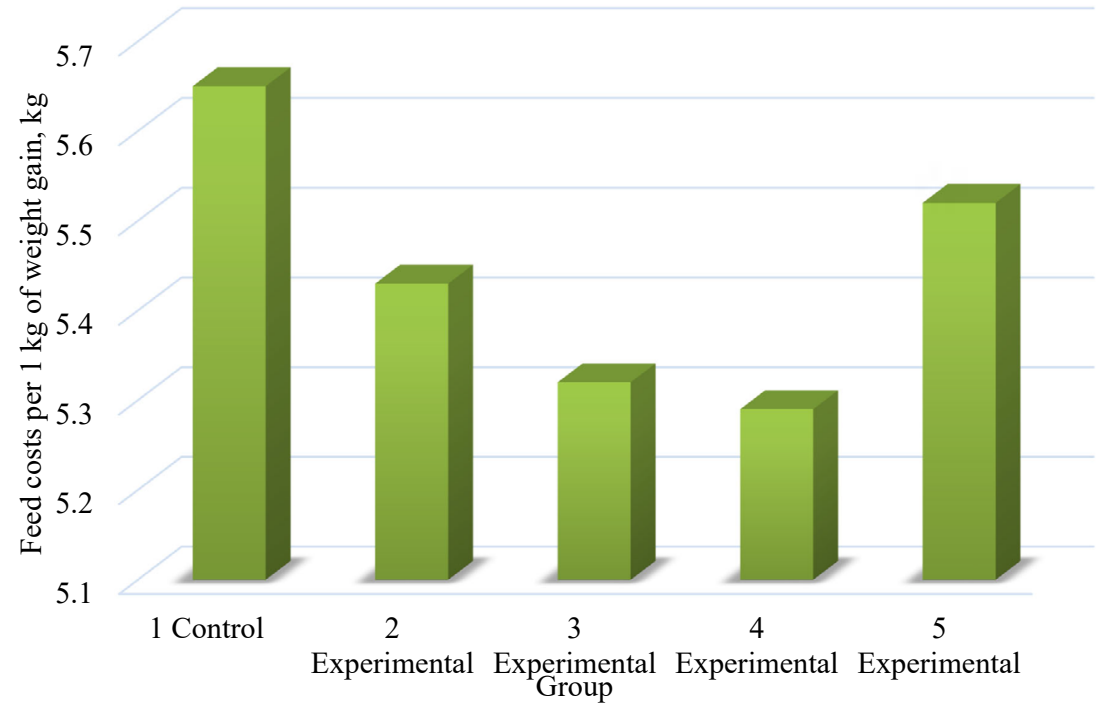

3: Feed costs per $1 \mathrm{~kg}$ of weight gain, $\mathrm{kg}$

The table shows that the feeding of the organic form of Coper in the feed for young rabbits grown for meat has contributed to the improvement of the digestibility of organic matter, crude protein, crude fiber and nitrogen free extractives substances. Among all the experimental groups, the best indices of nutrient digestibility of feed were in the rabbits of the $4^{\text {th }}$ experimental group, which in the composition of the feed fed coppermixedligand, which covered a deficit of this element by $50 \%$ metal chelate from the amount of Cuprum of the $2^{\text {nd }}$ experimental group.

Compared to the control group, the digestibility rate of organic feed matter in these animals increased by $3.7 \%$. This increase was due to an increase in the digestibility of crude protein - by $4.5 \%$, crude fat -0.5 , crude fiber -4.6 and nitrogenfree extractives substances - 3.7\%. Animals in the other experimental groups also increased the control group by $0.5-5.0 \%$ in nutrient digestibility.

Along with the live weight of rabbits, a significant indicator of the efficiency of balanced feeding of animals is the feed consumption per $1 \mathrm{~kg}$ of live weight gain (Fig. 3).
According to the results of the experiment, rabbits of the $2^{\text {nd }}$ experimental group during the whole period of the experiment ate $4.0 \%$ less feed than the counterparts of the $1^{\text {st }}$ control group. The difference in this indicator between animals of the $3^{\text {rd }}, 4^{\text {th }}$ and $5^{\text {th }}$ experimental groups and control was 4.6; 5.0 and $1.8 \%$. The analysis of the data on the consumption of mixed fodder with Cuprum sulfate and chelate in experimental rabbits per 1 head differs slightly, however, if we calculate the costs of feed per unit of weight gain, we observe that the use of organic form of coppermixedligand impact on the productive effect of feed.

Feed costs per $1 \mathrm{~kg}$ of body weight gain in animals of the $3^{\text {rd }}$ and $4^{\text {th }}$ experimental groups decreased compared to the control group by $5.8 \%$ and $6.3 \%$. For rabbits of the $2^{\text {nd }}$ and $5^{\text {th }}$ experimental groups, this indicator was lower than in the control group by $3.9 \%$ and $2.3 \%$ respectively.

\section{DISCUSSION}

Inorganic salts of transition metals (Zinc, Copper, Iron, Manganese) due to low digestibility pass through the intestine and in combination 
with associated salts of heavy metals pollute the environment. Copper is an important component of metalloproteins that regulate redox processes of cellular respiration, photosynthesis, assimilation of molecular nitrogen (Darmohray et al., 2015).

For a long time, inorganic salts of microelements (chlorides, nitrates, sulfates, carbonates), which are characterized by low bioavailability and are absorbed by the body of animals by $15-25 \%$, were used to balance the diets of animals by micronutrients. In addition, the balancing of animal feed due to inorganic salts leads to environmental pollution. Studies have shown that the body absorbs the best trace elements of organic origin by 85-90\%, so they are needed to ensure the optimal rate of animals much less than inorganic salts (Smetanina et al., 2017). Meanwhile, organic compounds of trace elements, especially chelate complexes are characterized by high bioavailability. They are easily absorbed in the intestine, enter the blood and lymph and enter all organs where they interact (Paik, 2001; Dębski, 2016).

Analysis of domestic and foreign studies shows that the problem of better absorption of nutrients from feed, especially minerals in the form of organic compounds, is being studied by a number of scientists. Livestock experts are developing various ways to reduce the level of heavy metals in animal diets, excretion with metabolic products and their entry into the environment, increase the degree of assimilation, which offer to use trace element compounds with amino acids, is chelate complexes (Eren et al., 2012; Mamchenko et al., 2013). Therefore, most studies are currently aimed at studying the effect of metal chelates on the productivity of cattle and pigs, less often - poultry.

Studies have shown that chelating compounds have a positive effect on productivity, metabolism in animals (Beshkenadze et al., 2016). To date, an effective source of enrichment of copper rations is carbonate, chloride and sulfate of this element, which have good solubility in water. Therefore, they are rapidly excreted from the body and have a low level of assimilation (Bondar et al., 2017). When they are introduced into the premixes, the crystalline water contained in the sulfate molecules can be released during storage under the influence of various factors, resulting in an intensification of the destruction of both vitamins and trace elements. Therefore, sulfates are dangerous than mixed ligand complexes (Makartsev et al., 2013).

The use of basal feed supplemented with copper in organic form has minimized egg loss. However, the best results (lower egg loss, higher specific weight and higher weight of eggs) were obtained with the basal feed supplemented with microminerals $\mathrm{Zn}+\mathrm{Mn}+\mathrm{Cu}$ in organic form (Maciel et al., 2010).

Studies have shown that the highest average daily milk yield of natural fat had cows of the $3^{\text {rd }}$ experimental group, which consumed as part of the feed mixed ligand cobalt complex in the amount of $75 \%$ metal concentration, which exceeded the control group by $4.4 \mathrm{~kg}$, respectively ( $\leq 0.01$ ), or $9.7 \%$ (Smetanina et al., 2017). Unfortunately, inorganic sources are poorly assimilated and ionize easily, yielding low bioavailability. Found manganese sulfate (32.5\% elemental Mn) in corn/soy diet had 1-6\% bioavailability, providing only $2 \%$ of the manganese to be utilized. Minerals found in food are bound to proteins. In a similar fashion, amino acids are protected by the ring structure in a mineral chelate (Dayyani et al., 2013). According to scientists (Xu et al., 2013) both excessive and insufficient amounts of trace elements of inorganic or organic origin can cause metabolic disorders. The absence or lack of these components in the diet of animals causes significant disorders and functional changes in the body and, consequently, a number of diseases that lead to reduced productivity, reproductive function and preservation of young animals.

\section{CONCLUSION}

The use of the organic form of coppermixedligand in the mixed fodder for young rabbits grown for meat in the amount of $3.91 \mathrm{~g} / \mathrm{t}$ or $50 \%$ at metal chelate helped increase the average daily growth of these animals by $4.7-13.9 \%$ and resulted the increase in the live weight of the experimental animals by $4.9-8.7 \%$. The use of mixed fodder with coppermixedligand helped to reduce feed costs per $1 \mathrm{~kg}$ of body weight gain of these animals by $2.3-6.3 \%$, and the nutrient digestibility of feed by $0.5-4.6 \%$, which was one of the factors increasing the live weight gain of rabbits of the experimental groups. Due to the fact that in Ukraine today there are no norms of mineral nutrition of all sex and age groups of rabbits, it is necessary to conduct a number of deep studies in order to determine the optimal doses of copper in the diet and sources of its receipt.

\section{REFERENCES}

BESHKENADZE, I., CHAGELISHVILI, A., BEGHELURI, G., ZHORZHOLIANI, N., GOGALADZE, M., UROTADZE, S. and KLARJEISHVILI, N. 2016. New generation premixes for rabbit nutrition. Annals of Agrarian Science, 14(4): 288-291. 
BONDAR, V. O. and YAREMA, M. A. 2017. The role of trace elements in life. In: Proceedings of the XVI International scientific-practical conference of faculty, graduate students and students "Actual problems of veterinary medicine”. Pp. 45-46.

COBANOVA, K., CHRASTINOVÁ, L., CHRENKOVÁ, M. et al. 2018. The effect of different dietary zinc sources on mineral deposition and antioxidant indices in rabbit tissues. World Rabbit Science, 26(3): 241-248.

DARMOHRAY, L. M. and SHEVCHENKO, M. E. 2015. Productive indicators of young rabbits by intensive cultivation technology. In: Technology of production and processing of livestock products: a collection of scientific papers. Bila Tserkva, pp. 16-22.

DAYYANI, N., BEYKI BANDAR ABADI, M. and AMIR ABADI FARHANI, A. 2013. Cheated minerals in animal nutrition. Int. J Adv. Biol. Biom. Res., 1(11): 1387-1391.

DĘBSKI, B. 2016. Supplementation of pigs diet with zinc and copper as alternative to conventional antimicrobials. Polish Journal of Veterinary Sciences, 19(4): 917-924.

EREN, V., GULES, O., EREN, U. and NURI ASTI, R. 2012. The Utilization of Organic Copper and Zinc in the Feeding of Sheep During the Pre and Post-Partum Period. Journal of Animal and Veterinary Advances, 11(7): 890-897.

JOHNSON-DELANEY, C. 2006. Anatomy and Physiology of the Rabbit and Rodent Gastrointestinal System. Proc. Assoc. Avian Vet., 10: 9-17.

MACIEL, M. P., SARAIVA, E. P., AGUIAR, É. D. F., RIBEIRO, P. A. P., PASSOS, D. P. and SILVA, J. B. 2010. Effect of using organic microminerals on performance and external quality of eggs of commercial laying hens at the end of laying. R. Bras. Zootec., 39(2): 344-348.

MAERTENS, L. and COUDERT, P. (Eds.). 2006. Recent advances in rabbit sciences. ILVO.

MAERTENS, L., PÉREZ, J. M., VILLAMIDE, M., CERVERA, C., GIDENNE, T. and XICCATO, G. 2002. Nutritive value of raw materials for rabbits: EGRAN tables 2002. World Rabbit Science, 10(4): 157-166.

MAKARTSEV, N. G. 2013. Influence of premixes with different additions of iron, zinc and copper on productivity, metabolism and supply of vitamins and microelements of young pigs. Effective feed for the year, 6: 18-22.

MAMCHENKO, V. Y. 2013. The use of metal chelates in animal diets. Bulletin of Dnipropetrovsk State Agrarian University, 2: 145-148.

MATEOS, G. G., GARCÍA-REBOLLAR, P. and DE BLAS, C. 2020. Minerals, vitamins and additives. In: Nutrition of the Rabbit. $3^{\text {rd }}$ Edition. CAB International, pp. 126-158.

PAIK, I. K. 2001. Application of chelated minerals in animal production. Asian-australasian Journal of Animal Sciences, 14: 191-198.

PREDIERI, G., ELVIRI, L., TEGONI, M., ZAGNONI, I., CINTI, E., BIAGI, G., FERRUZZA, S. and LEONARDI, G. 2005. Metal chelates of 2-hydroxy-4-methylthiobutanoic acid in animal feeding. Part 2: Further characterizations, in vitro and in vivo investigations. Journal of Inorganic Biochemistry, 99(2): 627-636.

SMETANINA, O. V., IBATULIN, I. I., BOMKO, V. S., BOMKO, L. G. and KUZMENKO, O. A. 2017. Influence of mixed ligand complex of cobalt on its metabolism in the organism of highly productive cows. Ukrainian Journal of Ecology, 7(4): 559-563.

TCHOUNWOU, P. B., YEDJOU, C. G., PATLOLLA, A. K. and SUTTON, D. J. 2012. Heavy Metals Toxicity and the Environment. In: LUNCH, A. (Ed.). Molecular, Clinical and Environmental Toxicology. Vol. 3. EXS series Vol. 101, pp. 133-164.

XU, Y., YU, W., MA, Q. and ZHOU, H. 2013. Accumulation of copper and zinc in soil and plant within ten-year application of different pig manure rates. Plant Soil Environ, 59(11): 492-499.

ZHU, Z., YAN, L., HU, S., AN, S., LV, Z., WANG, Z., WU, Y., ZHU, Y., ZHAO, M., GU, C. and ZHANG, A. 2019. Effects of the Different Levels of Dietary Trace Elements From Organic or Inorganic Sources on Growth Performance, Carcass Traits, Meat Quality, and Faecal Mineral Excretion of Broilers. Archives of Animal Nutrition, 73(4): 324-337.

\section{Contact informacion}

Oksana Kuzmenko: oksanakuzmenko79@gmail.com

Vitalii Bomko: vitalijbomko@gmail.com

Olena Tytariova: olenakosyanenko@gmail.com

Anna Horchanok: anna.horchanok@dsau.dp.ua

Serhii Babenko: babenkosergij@gmail.com

Mykhailo Slomchynskyi: mihajloslomcinskij@gmail.com

Oleksandr Cherniavskyi: chernavskijoleksandr@gmail.com 
